\title{
УДК 371.314.6:372:53
}

\section{Барладим Валентина Миколаївна}

аспірант відділу дослідження і проектування навчального середовища Інститут інформаційних технологій і засобів навчання НАПН України, м. Київ, Україна barladim_valya@ukr.net

\section{ПЕДАГОГІЧНІ ТЕХНОЛОГІЇ: АНАЛІЗ ТА ПЕРСПЕКТИВИ ЇХ ВИКОРИСТАННЯ}

\begin{abstract}
Анотація. Сучасна педагогічна теорія і практика характеризуються великою кількістю різноманітних підходів, теорій, шкіл та навчально-виховних систем. Отже, під час реалізації навчально-виховного процесу педагог має вміло поєднувати на практиці новітні підходи і педагогічні ідеї, що вже пройшли випробування часом.

На сьогодні в Україні проголошені принципи гуманізації і демократизації освіти, безперервної освіти впродовж життя, варіативності освітнього процесу. Для реалізації даних принципів сучасна педагогічна наука пропонує використовувати різноманітні педагогічні технології. У статті проаналізовано історичні аспекти виникнення поняття «педагогічні технології», сучасні підходи щодо його визначення; запропоновані педагогічні технології. що можуть бути використані під час дистанційного навчання.
\end{abstract}

Ключові слова: педагогічні технології; навчально-виховний процес; інформаційнокомунікаційні технології в освіті; дистанційне навчання.

\section{1. ВСТУП}

Постановка проблеми. Створення життєздатної системи безперервного навчання i виховання для досягнення високих освітніх рівнів, забезпечення можливостей постійного духовного самовдосконалення особистості, формування інтелектуального i культурного потенціалу як найвищої цінності нації - $є$ основним завданням сучасної педагогічної теорії і практики.

На сьогоднішній день провідними науковцями проголошено реформування всіх напрямів й етапів освіти і виховання; пропонуються нові принципи - пріоритетності освіти, демократизації, багатоукладності та варіативності тощо. Крім того, передбачається глибоке реформування змісту, форм, методів підготовки педагогічних працівників усіх ланок освітньої галузі, підготовка педагогів, які здатні, використовуючи новітні педагогічні технології, сформувати цілісну, всебічно розвинену особистість [16].

Знання, правильний добір та доцільне використання інноваційних педагогічних технологій може позитивно впливати на ефективність навчально-виховного процесу, порівняно 3 традиційними заняттями. Попри це, за рахунок реалізації принципу варіативності педагог може творчо підійти до конструювання навчально-виховного процесу.

Аналіз останніх досліджень і публікацій. Аналіз сучасної науково-педагогічної i методичної літератури 3 питань класифікації, систематизації та використання в навчально-виховному процесі новітніх педагогічних технологій показує, що проблема $є$ актуальною і широко досліджуваною.

Питання щодо проектування i використання педагогічних технологій розглядається у працях В. В. Афанасьєва (проектування педагогічних технологій у вищій школі, технологічний підхід до управління педагогічними системами), О. В. Глузмана (інноваційні технології у системі вищої педагогічної освіти), О. С. Падалки (педагогічні технології у підготовці майбутнього вчителя), І. А. Зязюна 
(майстерність вчителя у застосуванні педагогічних технологій), Т. С. Назарової (використання педагогічних технологій у загальноосвітніх школах під час навчання точних наук), Г. К. Селевко (систематизація педагогічних технологій), Г. П. П'ятакової i Н. М. Заячківської (застосування технологічного підходу у вищій школі) [14], О. М. Пєхоти (підготовка майбутнього вчителя до використання особистісноорієнтованих технологій).

Поняття «педагогічні технології» майже століття використовується дослідниками i практиками для опису навчально-виховного процесу, але й нині немає його усталеного визначення. Так, наприклад, у країнах США і Західної Свропи поняття трансформувалося від ідеї впровадження технічних засобів навчання в освітньовиховний процес до ідеї організації навчання на засадах системного підходу, створення таких дидактичних систем, у яких раціонально поєднувалися усі складники забезпечення успішного навчання - технічні й людські ресурси, час і місце навчання.

У вітчизняній педагогіці поняття «педагогічні технології» має свою історію. Так, наприклад, можна виділити подані нижче етапи [10].

I етап (30 pp. XX століття) - виникає поняття «шкільна технологія». У педагогіці ведеться пошук аналогій між виробничими процесами і процесом навчання і виховання нового покоління.

II етап (60-70 pp. XX століття) - в навчально-виховний процес активно залучаються технічні засоби (діапроектори, програвачі тощо). У науково-педагогічних джерелах використовують термін «педагогічні технології», що, найчастіше, визначає навчально-виховний процес із використанням технічних засобів.

III етап (80 pp. - до нашого часу) - пошук нового змісту поняття «педагогічні технології». Формується ідея системності у навчанні, як гаранту оптимізації й ефективності освітнього процесу. З'являються нові напрями в освіті, оновлюється педагогічна лексика, створюються авторські концепції і школи.

Мета статті. Сучасні освітні тенденції кидають виклик педагогові, як учаснику й організатору начального і виховного процесу. Перед ним стоїть завдання глибокого розуміння основних категорій і закономірностей педагогіки, знання методів навчання i виховання, форм організації навчально-виховного процесу, розуміння особистості учня, складності й багаторівневості структури якостей кожної особистості [16].

Враховуючи нові підходи до освіти, навчання та виховання, а також низку державних документів, які регламентують пріоритетні напрями і форми освітньовиховного процесу, зокрема Національну стратегію розвитку освіти в Україні на період до 2021 року, Положення про дистанційне навчання (2013 року), Положення про електронні освітні ресурси, Державну цільову програму впровадження у навчальновиховний процес загальноосвітніх навчальних закладів інформаційно-комунікаційних технологій «Сто відсотків» на період до 2015 року та інші, необхідно провести аналіз існуючих педагогічних технологій i 3 'ясувати можливість їх використання у дистанційній освіті учнів.

\section{2. МЕТОДИ ДОСЛІДЖЕННЯ}

Під час написання цієї статті ми використовували такі теоретичні методи дослідження: аналіз проблеми у науково-методичній літературі; ретроспективний аналіз умов розвитку i функціонування понять «педагогічна/освітня технологія» i «педагогічна система»; метод конкретизації для диференціації й уточнення понять «педагогічна технологія», «педагогічна техніка» і «педагогічна система». 


\section{3. РЕЗУЛЬТАТИ ДОСЛІДЖЕННЯ}

Сучасна педагогічна спільнота веде активний пошук дієвих i ефективних педагогічних технологій. Розглядаються питання щодо застосування тих чи інших технологій у навчанні певних предметів; можливості використання педагогічних технологій, що вже довели свою ефективність в одній освітній галузі, в інших галузях освіти; доцільності їх використання для різних вікових категорій учнів.

Нами 3'ясовано, що існують різні наукові підходи щодо визначення поняття «педагогічні/освітні технологій». Для зручності, класифікуємо їх так, як подано нижче.

1. Педагогічні технології як засіб - створення і застосування методичного інструментарію, апаратури, навчального обладнання. Представниками такої думки є С. А. Смірнов, В. Ф. Паламарчук, Б. Т. Лихачов.

2. Педагогічні технології як спосіб - процес комунікації (спосіб, техніка виконання навчальних завдань, модель), що базується на певному алгоритмі, системі взаємодії учасників освітньо-виховного процесу. Таку думку висловлюють С. Гібсон, В. П. Беспалько, А. М. Кушнір та інші.

3. Педагогічні технології як наука - велика галузь знань, що спирається на дані соціальних, естетичних наук та наук управління. Займається конструюванням оптимальних освітніх систем і проектуванням навчальних процесів, включає в себе засоби діагностики учнів, наприклад - навчальні досягнення, психофізичний стан, індивідуальні особливості тощо (В. В. Гузєєв, С. Ведемейер, Р. Кауфман).

4. Педагогічні технології як багатовимірне поняття - система функціонування всіх компонентів педагогічного процесу, що діє на науковій основі, запланована в часі і просторі та приводить до очікуваних результатів. (В. I. Боголюбов, Г. К. Селевко, В. В. Давидов).

Існування нині багатьох роз'яснень щодо поняття «педагогічна/освітня технологія» говорить про те, що педагогіка знаходиться на шляху переосмислення i розвитку всього навчально-виховного процесу, понятійної і методичної бази й ролей учасників педагогічної взаємодії, що дає підставу застосувати ідеї технологічності педагогічного процесу для пошуку і використання педагогічних технологій під час дистанційної навчально-виховної взаємодії.

На нашу думку, педагогічні технології, які використовуються для реалізації дистанційного навчання - це спосіб навчально-виховної взаємодії, що базується на певному алгоритмі й реалізується за допомогою сучасних інформаційнокомунікаційних технологій, апаратури тощо. Зауважимо, що дистанційне навчання [13] — це індивідуалізований процес набуття знань, умінь, навичок і способів пізнавальної діяльності людини, який відбувається в основному за опосередкованої взаємодії віддалених один від одного учасників навчального процесу у спеціалізованому середовищі, яке функціонує на базі сучасних психолого-педагогічних та інформаційнокомунікаційних технологій.

У загальноосвітніх навчальних закладах навчально-виховний процес за дистанційною формою організується відповідно до робочих навчальних планів за умови їх адаптації до дистанційної форми навчання. Строк навчання учнів за дистанційною формою має бути не меншим ніж за денною формою. Перш за все, дистанційне навчання зорієнтоване на осіб з особливими потребами; обдарованих дітей, які спроможні самостійно опанувати навчальну програму; дітей, які проживають у важкодоступних до навчального закладу населених пунктах; осіб, які бажають отримати додаткові знання паралельно 3 навчанням у школі. Також можливість використання технології дистанційного навчання передбачено під час карантинів, 
навчання учнів під час хвороби, вивчення додаткових (факультативних) предметів, участі у дистанційних олімпіадах і конкурсах, отримання консультацій. Водночас перелік предметів чи тем навчальних програм, видів навчальних занять, які здійснюються за технологіями дистанційного навчання, визначаються навчальним закладом за погодженням із законними представниками учня. Для забезпечення дистанційного навчання загальноосвітній навчальний заклад може створювати власні веб-ресурси або використовувати вже існуючі, що підлягають перевірці у навчальному закладі.

У Положенні про дистанційну освіту знаходимо роз'яснення таких понять, як:

- психолого-педагогічні технології дистанційного навчання - система засобів, прийомів, кроків, послідовне здійснення яких забезпечує виконання завдань навчання, виховання і розвитку особистості;

- технології дистанційного навчання - комплекс освітніх технологій, включаючи психолого-педагогічні й інформаційно-комунікаційні, що надають можливість реалізувати процес дистанційного навчання у навчальних закладах і наукових установах;

- інформаційно-комунікаційні технології дистанційного навчання - технології створення, накопичення, зберігання та доступу до веб-ресурсів (електронних ресурсів) навчальних дисциплін (програм), а також забезпечення організації i супроводу навчального процесу за допомогою спеціалізованого програмного забезпечення і засобів інформаційно-комунікаційного зв’язку, у тому числі Інтернету.

Щодо поняття «Інтернет орієнтовані педагогічні технології», які є підмножиною педагогічних технологій теж існують різні тлумачення, що пов'язано з різноманітним трактуванням родового поняття - педагогічна технологія. Так Ю. О. Жук і О. М. Соколюк пропонують інтерпретувати Інтернет орієнтовані педагогічні технології як концепт, тобто як комплексну розумову одиницю, що відбиває індивідуальні і суспільні подання й оцінки певного педагогічного явища або процесу [7].

Також, в науково-педагогічній літературі зустрічається поняття «інформаційнотелекомунікаційні технології в освіті» - технології, що використовують спеціальні технічні інформаційні засоби. Як стверджує Р. С. Гуревич [5, 364-365], будь яка педагогічна технологія — це інформаційна технологія, оскільки основу технологічного процесу навчання становить інформація і їі рух (перетворення). Так, на думку автора, інформаційно-телекомунікаційна технологія навчання — це комп'ютерна технологія, яка базується на використанні певної формалізованої моделі змісту, що представлена педагогічними програмними засобами, записаними в пам'яті комп'ютера, i можливостями телекомунікаційних мереж.

Наявність широкого спектру визначення понять - «педагогічна технологія», «Інтернет орієнтована педагогічна технологія», «технологія дистанційного навчання» тощо; досліджень 3 проблеми використання сучасних педагогічних технологій i залучення в навчально-виховний процес новітніх інформаційно-комунікаційних технологій свідчить про те, що застосування педагогічних технологій є пріоритетним напрямком навчально-виховної взаємодії під час занять у школі, а також у процесі дистанційного навчання.

Технологізація навчально-виховного процесу відкриває широкі можливості перед педагогом і учнем щодо добору й варіювання форм, методів та способів опанування навчальною інформацією. Однак, для того щоб мати можливість вільного і правильного вибору ефективних педагогічних технологій, потрібно знати їхню структуру, якісну характеристику, критерії технологічності педагогічного процесу, орієнтуватися в 
методологічних підходах до навчально-виховного процесу, знати наукові концепції розвитку особистості тощо.

Отже, педагогічна технологія — це процес, що включає в себе всі аспекти освіти й має складну структуру, яку можна характеризувати як по горизонталі, так і по вертикалі $[15 ; 16]$. Горизонтальна структура педагогічних технологій включає в себе три компоненти.

1. Науковий - педагогічна технологія як частина науки, що вивчає і розробляє зміст і методи освіти та проектує педагогічні процеси.

2. Процесуально-описовий - педагогічна технологія як модель, опис мети, змісту, методів та засобів, алгоритму дій, що використовуються для досягнення передбачуваних результатів.

3. Процесуально-діяльнісний - педагогічна технологія як процес реалізації діяльності об'єктів і суб'єктів навчально-виховного процесу, функціонування інструментарних і методологічних педагогічних засобів.

Вертикальна структура педагогічних технологій $\epsilon$ такими взаємозалежними рівнями освітніх технологій.

4. Метатехнології - загально педагогічні технології, що охоплюють цілісний освітньо-виховний процес на рівні держави, регіону, навчального закладу. Наприклад: технологія дошкільної освіти, технологія розвиваючого навчання тощо.

5. Макротехнології (галузеві) - педагогічні технології, що охоплюють діяльність в межах певної педагогічної галузі, навчальної дисципліни. Наприклад: технологія викладання певного предмету.

6. Мезотехнології (модульно-локальні) - технології реалізації окремих частин навчально-виховного процесу i спрямовані на реалізацію локальних дидактичних, методичних або виховних задач. Наприклад: технологія вивчення певної теми, технологія засвоєння знань тощо.

7. Мікротехнології - педагогічні технології, що вирішують вузьке коло задач $\mathrm{i}$ відносяться до індивідуальної взаємодії педагогічного процесу. Наприклад: технологія навичок письма.

Для реалізації дистанційної навчально-виховної взаємодії, на нашу думку, варто брати до уваги всі компоненти за горизонталлю; а за вертикаллю рівень метатехнологій, як загально педагогічних технологій, що охоплюють освітньовиховних процес на рівні держави i рівень мікротехнологій, як педагогічних технологій, що вирішують вузьке коло задач і відносяться до індивідуальної взаємодії.

Але, на сьогоднішній день існують й інші думки щодо визначення поняття «педагогічна технологія», наприклад С. О. Сисоєва [5, 661-662], аналізуючи різні підходи до визначення даної категорії, говорить про те, що педагогічні технології розглядаються багатоаспектно, а саме:

- як раціональний спосіб досягнення свідомо сформульованої освітньої (навчальної, виховної) мети (М. Вулман, І. Лернер, Б. Ліхачов, П. Сікорський, Рада $з$ педагогічних технологій Великої Британії);

- як наука (Г. Селевко);

- як педагогічна система (В. Безпалько, С. Сисоєва, Д. Чернилевський);

- як педагогічна діяльність (А. Нісімчук);

- як системно-діяльнісний підхід до освітнього (навчального) процесу (Г. Еллінгтон, Н. Кузьміна, П. Мітчелл, Ф. Персиваль, О. Пехота, П. Самойленко);

- як система знань (В. Генецинський, Т. Назарова, В. Онищук, Ю. Турчанінова, Національний центр програмованого навчання Великої Британії); 
- як мистецтво педагога (І. Прокопенко, Н. Тализіна, В. Шепель);

- як модель (В. Ченців);

- як засіб оптимізації і модернізації освітнього процесу (Ф. Янушкевич);

- як процесуальний компонент (складова) освітнього (навчального) процесу (М. Кларін);

- як інтегративний підхід до освіти (П. Мітчелл, Д. Фін).

Також існує певна відмінність у розумінні структури педагогічних технологій. Так, наприклад у «Енциклопедії освіти» (за ред. В. Г. Кременя) [5] визначаються такі структурні компоненти:

- концептуальна основа;

- змістова частина навчання і виховання, розвитку учнів (цілі - загальні й конкретні; зміст навчального, виховного, розвивального матеріалу);

- процесуальна частина — технологічний процес (організація навчальновиховного процесу; методи і форми навчально-виховної діяльності школярів; методи і форми роботи вчителя; діяльність учителя у сфері керування педагогічним процесом; діагностика педагогічного процесу).

При цьому концептуальна основа це - короткий опис ідей, гіпотез, принципів, які сприяють розумінню, трактовці побудови вияву керівних ідей певної педагогічної технології. Змістова частина - визначає загальні й конкретні цілі впровадження, зміст, розвиток особистісних структур, на які спрямована педагогічна технологія. У процесуальній частині описується технологічний процес, його організація, методи та форми діяльності всіх суб'єктів навчально-виховного процесу, його етапи, регламент, корекція дій та час, що має бути витрачений для реалізації процесу. Для успішної реалізації навчально-виховного процесу за дистанційною формою важливо дотримуватися даної структури кожної з обраних педагогічних технологій.

Поряд із тим, що не існує однозначного визначення поняття «педагогічні технології», деякі вчені пропонують виділити як окреме поняття «інноваційні педагогічні технології». Так, наприклад [9] автором дається визначення інноваційних педагогічних технологій, як таких, що спроможні вивести систему освіти на новий рівень і задовольнити потреби суспільства в новому поколінні спеціалістів професіоналів. Проблема такого різноманітного трактування поняття викликає непорозуміння між учасниками педагогічного процесу. Педагоги-практики часто розуміють під педагогічною технологією педагогічну техніку, педагогічну майстерність або педагогічну систему.

Також, варто зазначити, що педагогічні технології можуть застосовуватися різними викладачами, що також є причиною різних результатів. Саме в цих випадках мова йде про педагогічну майстерність, педагогічну техніку виконання тієї чи іншої технології. На нашу думку, для реалізації ефективного навчально-виховного процесу важливо розмежовувати такі поняття як - «педагогічна система», «педагогічна технологія» та «педагогічна техніка».

Отже, педагогічна система - це полісистемне утворення, що складається 3 багатьох взаємодіючих i взаємодоповнюючих частин. Педагогічна система розглядається:

- у широкому розумінні - як об'єднання учасників педагогічного процесу, де їх діяльність $\epsilon$ джерелом педагогічної мети і засобом її досягнення одночасно;

- у вузькому розумінні - соціально-обумовлена цілісність учасників педагогічного процесу 3 їх матеріальними й духовними цінностями, що взаємодіють на основі співробітництва між собою і 3 навколишнім середовищем, котре спрямоване на формування і розвиток особистості. 
Основними факторами успішного функціонування сучасних педагогічних систем $€$ : відповідність поставленої мети віковим й особистісним особливостям учнів; зміст, кількість і якість навчального матеріалу, спосіб, структура, доступність його викладання та ін.; методи і прийоми викладання і учіння, технічні засоби навчання та ін.; фактори, що стосуються педагогів і учнів (рівень педагогічної підготовки вчителя, рівень його знань, особистісні характеристики та ін.); фактори, що забезпечують ефективність зворотнього зв'язку у педагогічному процесі (форми контролю, його періодичність тощо) [5].

Слід зауважити, що часто поняття «педагогічна система» персоніфікується i характеризує науково-практичну діяльність відомих педагогів (педагогічна система В. О. Сухомлинського, А. С. Макаренка та ін.) Попри це, у педагогічній практиці і навчально-методичній літературі поняття педагогічна технологія використовується як синонім педагогічної системи. На нашу ж думку, педагогічна технологія є складовою педагогічної системи і є її послідовним практичним втіленням.

Педагогічна техніка — це комплекс знань умінь і навичок, необхідних педагогу для чіткої й ефективної організації навчальних занять, ефективного застосування на практиці обраних методів педагогічного впливу як на окремих учнів, так і на дитячий колектив у цілому [3]. Елементами педагогічної техніки $є-$ володіння мистецтвом спілкування 3 дітьми, оволодіння культурою мови, почуття темпу в педагогічних діях тощо.

Попри це, варто зазначити, що виходячи із закономірностей i структури дидактичного процесу, педагогічні технології можна поділити на три основні групи:

- мотиваційні педагогічні технології - занурюють учнів у навчальнопізнавальну діяльність; орієнтовані на розвиток внутрішньої мотивації особистості; створюють атмосферу емоційної розкутості, позитивного настрою до діяльності; забезпечують оптимальне педагогічне спілкування; індивідуальний підхід до учнів; орієнтують на практичне застосування вивченого матеріалу; допомагають організувати зворотній зв'язок, що базується на інформуванні;

- діяльнісні технології - пов'язані з безпосередньою взаємодією педагога й учнів. Можуть бути розподілені за такими ознаками: за призначенням технології засвоєння теоретичних знать, технології виконання практичних дій; за використанням - індивідуальні (призначені для виконання одного конкретного завдання), загально педагогічні (застосовуються для засвоєння будь-якого завдання, незалежно від його конкретного змісту); за метою засвоєння і рівнем самостійної пізнавальної діяльності — репродуктивні, проблемно-розвивальні, евристичні; технології управління [11].

Також до педагогічних технологій висуваються певні вимоги: мати попит у педагогічній практиці; відповідати системі «педагог, який навчається» та бути готовою до тиражування; бути універсальною щодо застосування у різних предметних методичних системах. До того ж, існують вимоги щодо моделювання навчального процесу — цілісність і циклічність моделі процесу навчання; технологізація його інформаційної моделі. А також вимоги до нормалізації проекту навчального процесу як продукту функціонування педагогічних технологій - нормування проекту процесу навчання (навчального часу, об'єму дидактичної інформації, інтенсивності засвоєння інформації тощо); формування робочого поля, у якому функціонує педагогічна технологія [4]. Виконання даних вимог, на нашу думку, створює позитивні умови для коректного та ефективного застосування педагогічних технологій в освітньо-виховному процесі. 
Отже, для правильного використання педагогічних технологій під час навчальновиховного процесу і досягнення очікуваного результату, педагог має враховувати такі фактори: мета і завдання дисципліни, що вивчається; специфіка певного навчального предмету; рівень своєї компетентності; рівень знань учнів; педагогічні можливості обраної технології для вирішення конкретної педагогічної задачі; матеріально-технічне й інформаційне забезпечення навчального процесу.

На сьогоднішній день можна виділити такі педагогічні технології, що відповідають вищезазначеним вимогам i набули поширення в практиці вищої i загальної освіти.

1. Особистісно-орієнтовані технології - передбачають підвищення ефективності навчально-виховного процесу шляхом його індивідуалізації і диференціації, створення атмосфери комфорту в процесі навчання, співробітництво педагога й учня на суб'єкт-суб'єктному рівні, виявлення й урахування суб' єктивного досвіду кожного учня.

2. Проектні технології — передбачають розв'язання різних проблем із використанням дослідницьких методів, стимулювання інтересу учнів до самостійного здобуття знань, розвивають уміння орієнтуватися в інформаційному просторі, позитивно впливають на розвиток критичного i творчого мислення.

3. Ігрові технології - передбачають використання в навчально-виховному процесі різноманітних навчально-педагогічних ігор, ігрову імітацію певної професійної діяльності, спонукають до самостійної пізнавальної діяльності, що спрямована на пошук, обробку та засвоєння навчальної інформації.

4. Технології розвитку творчості - передбачають надання учням творчих завдань, що, у свою чергу, стимулюватиме їх до пізнавальної діяльності.

5. Діалогові технології - передбачають вирішення питань проблемного характеру (такі, що не мають однозначного вирішення в науці і практиці) шляхом діалогу.

6. Тренінгові технології - передбачають відпрацювання певних алгоритмів навчально-пізнавальної діяльності та способів розв'язання різних видів завдань.

7. Розвивальна технологія - передбачає організацію навчально-виховної діяльності таким чином, щоб учень був спроможний знайти способи розв'язання будь-яких проблем у різних життєвих ситуаціях, спонукає учнів до різноманітних видів діяльності.

8. Технології диференційованого навчання - передбачають створення таких умов навчання, які б відповідали індивідуальним можливостям і здібностям певного учня, прогнозують різні рівні засвоєння знань (але не нижче обов'язкового мінімуму/стандарту).

9. Модульна технологія - передбачає формування навчального процесу за окремими функціональними блоками, відображеному у змісті, організаційних формах і методах, дає можливість навчатися з урахуванням індивідуального темпу засвоєння знань.

10. Технологія проблемного навчання - передбачає послідовне та цілеспрямоване представлення учням пізнавальних задач, під час вирішення яких учні активно засвоюють знання.

11. Інформаційні технології навчання - передбачають організацію навчальновиховного процесу 3 використанням електронних i iнформаційнокомунікаційних засобів, допомагають розвинути навички самостійної 
пізнавальної діяльності, готують до життя в інформаційному суспільстві й позитивно впливають на розвиток творчих можливостей особистості.

На нашу думку, дані педагогічні технології доцільно використовувати під час дистанційного навчання, оскільки вони відповідають всім вимогам, які висуваються до сучасних педагогічних технологій і надають можливість реалізувати ефективний процес дистанційного навчання у навчальних закладах.

\section{4. ВИСНОВКИ ТА ПЕРСПЕКТИВИ ПОДАЛЬШИХ ДОСЛІДЖЕНЬ}

1. Проаналізовано і виявлено історичні аспекти виникнення поняття «педагогічна технологія», з'ясовано як змінювався зміст даного поняття i як при цьому організовувався навчально-виховний процес.

2. 3'ясовано сучасний стан використання в науково-педагогічному середовищі поняття «педагогічна технологія». Виявилося, що на даний час науковці не прийшли до однозначного його трактування.

3. Проведений аналіз державних програм i проектів (Національна стратегія розвитку освіти в Україні на період до 2021 року, Положення про дистанційне навчання, Положення про електронні освітні ресурси, Державна цільова програма впровадження у навчально-виховний процес загальноосвітніх навчальних закладів інформаційно-комунікаційних технологій «Сто відсотків» на період до 2015 року та інші) свідчить про те, що застосування сучасних педагогічних технологій $\epsilon$ пріоритетним напрямком навчально-виховної взаємодії і відкриває широкі можливості щодо добору i варіювання форм, методів і способів опанування навчальною інформацією.

4. На нашу думку, педагогічна технологія $є$ складовою педагогічної системи і $є$ iii послідовним практичним втіленням. Попри це, педагогічна технологія передбачає чітку алгоритмізовану педагогічну взаємодію.

5. Запропонована низка сучасних педагогічних технологій, які доцільно використовувати під час навчально-виховного процесу за дистанційною формою. А саме: особистісно-орієнтовані технології, проектні технології, тренінгові технології, технології проблемного навчання та інші. Ці технології висвітлені у науковопедагогічній і методичній літературі, існують певні розробки щодо їх застосування під час вивчення певних предметів. Однак, на сьогоднішній день більшість розробок присвячена організації навчально-виховного процесу у вищій школі. Попри це, недостатньо чітко розглянуті функції кожного учасника навчально-виховного процесу під час застосування певних технологій. Що і може стати перспективою подальших досліджень.

\section{СПИСОК ВИКОРИСТАНИХ ДЖЕРЕЛ}

1. Афанасьев В. В. Проектирование педтехнологий / Афанасьев В. В. //Высш. образование в России. - 2001. — № 4. - С. 147-150.

2. Глузман А. В. Инновационные технологии обучения в системе университетского педагогического образования [Электронный ресурс] / А. В. Глузман // Проблемы и перспективы инновационного развития экономики : материалы десятой международной научно-практической конференции по инновационной деятельности. - Киев-Симферополь-Алушта, 2005. - Режим доступа : http://iee.org.ua/files/conf/conf_article39.pdf.

3. Гончаренко С. У. Український педагогічний словник / С. У. Гончаренко. — К. : Либідь, 1997. — $376 \mathrm{c}$.

4. Горовая В. И. Инновационная активность педагога / Горовая В. И., Петрова Н. Ф. // Современные проблемы науки и образования. - 2009. - № 3 - С. 149-153. 
5. Енциклопедія освіти / Акад. пед. наук України; головний ред. В. Г. Кремень. - К. : Юрінком Інтер, 2008. - $1040 \mathrm{c}$.

6. Державна національна програма «Освіта» («Україна XXI століття») [Електронний ресурс]. Режим доступу : http://zakon1.rada.gov.ua.

7. Жук Ю. О. Інтернет орієнтовані педагогічні технології: проблема інтерпретації поняття / [Електронний ресурс] / Жук Ю. О., Соколюк О. М. - Режим доступу : http://journal.iitta.gov.ua/index.php/itlt/article/view/713/527.

8. Іваненко К. В. Педагогічна система як чинник формування і розвитку особистості [Електронний ресурс] / Іваненко К. В. // Теоретико-методичні проблеми виховання дітей та учнівської молоді: зб. наук. праць. - Вип. 15, книга 1. — Кам'янець-Подільський : Видавець ПП Зволейко Д. Г., 2011. $528 \mathrm{c}$.

9. Кіяшко О. О. Інноваційні педагогічні технології підготовки молодших спеціалістів у вищих навчальних закладах I-II рівнів акредитації : дис. канд. пед. наук : 13.00 .04 / Кіяшко Олександр Олександрович. - Луганськ, 2001. - 262 с.

10. Педагогічні технології: теорія та практика : навчально-методичний посібник / за ред. проф. М. В. Гриньової. - Полт. держ. пед. ун-т. ім. В. Г. Короленка. - Полтава : АСМІ, 2006. — 230 с.

11. Петрова Н. Ф. Педагогические технологии управленческой деятельности преподавателя / Петрова Н. Ф. // Современные проблемы науки и образования. - 2009. - № 2 - С. 77-78.

12. Пєхота О. М. Освітні технології : навч.-метод. посіб. / [О. М. Пєхота, А. 3. Кіктенко, О. М. Любарська та ін.]. — К. : А.С.К., 2002. - 255 с.

13. Положення про дистанційне навчання [Електронний ресурс]. - Режим доступу : http://zakon4.rada.gov.ua.

14. П'ятакова Г. П. Сучасні педагогічні технології та методика їх застосування у вищій школі : навчально-методичний посіб ник для студентів та магістрантів вищої школи / П'ятакова Г. П., Заячківська Н. М. - Львів: Видавничий центр ЛНУ імені Івана Франка, 2003. — 55 с.

15. Селевко Г. К. Современные образовательные технологи : учебное пособие. / Селевко Г. К. - М. : Народное образование, 1998. - 589 с.

16. Селевко Г.К. Энциклопедия образовательных технологий : В 2 т. Т. 1 / Селевко Г. К. - М. : НИИ школьных технологий, 2006. - 816 с. (Серия «Энциклопедия образовательных технологий».)

Матеріал надійшов до редакиіï 21.10.2013 p.

\section{ПЕДАГОГИЧЕСКИЕ ТЕХНОЛОГИ: АНАЛИЗ И ПЕРСПЕКТИВЫ ИХ ИСПОЛЬЗОВАНИЯ}

\section{Барладым Валентина Николаевна}

аспирант отдела исследования и проектирования обучающей среды

Институт информационных технологий и средств обучения НАПН Украины, г. Киев, Украина barladim_valya@ukr.ne

Аннотация. Современная педагогическая теория и практика характеризуется большим количеством различных подходов, теорий, школ и учебно-воспитательных систем. Следовательно, при реализации учебно-воспитательного процесса педагог должен умело сочетать на практике новейшие подходы и педагогические идеи, которые уже прошли испытание временем. На сегодняшний день в Украине провозглашены принципы гуманизации и демократизации образования, непрерывного образования в течении всей жизни, вариативности образовательного процесса. Для реализации данных принципов современная педагогическая наука предлагает использовать различные педагогические технологии. В статье проанализированы исторические аспекты возникновения понятия «педагогические технологии», современные подходы к его определению; предложены педагогические технологии, которые могут быть использованы при дистанционном обучении.

Ключевые слова: педагогические технологии; учебно-воспитательный процесс; информационно-коммуникационные технологии в образовании; дистанционное обучение. 


\title{
PEDAGOGICAL TECHNOLOGIES: ANALYSIS AND PERSCPECTIVES OF THEIR USE
}

\section{Valentyna M. Barladym}

graduate student of the Department of research and learning environment design Institute of Information Technologies and Learning Tools, NAPS of Ukraine, Kyiv, Ukraine barladim_valya@ukr.net

\begin{abstract}
Modern pedagogical theory and practice is characterized by vast number of different approaches, theories, school and educational systems. Therefore educator must skillfully join on practice new approaches and pedagogical ideas checked by time when realizing educational process. Today in Ukraine there are declared principles of humanization and democratization of education, lifelong continuous education, variability of educational process. Modern pedagogical science offers various pedagogical technologies for realization of declared principles. In the article it is analyzed the historical aspects of nascence of concept "pedagogical technology", modern approaches of its definition and proposed a set of pedagogical technologies which can be used in process of distance education.
\end{abstract}

Keywords: pedagogical technology; educational process; information and communication technologies in education; distance education.

\section{REFERENCES (TRANSLATED AND TRANSLITERATED)}

1. Afanasiev V. V. Design of pedagogical technologies // Higher education in Russia. — 2001. — № 4. P. 147-150. (in Russian)

2. Hlusman A. V. Innovative educational technologies is system of university pedagogical education / A. V. Hlusman [online ] // Problems and perspectives of innovational economic development // Materials Tenth international scientific and practical conferension on innovation activity. - Kiev-Simferopol-Alushta, 2005. - Available from: http://iee.org.ua/files/conf/conf_article39.pdf. (in Russian)

3. Honcharenko S. U. Ukrainian pedagogical dictionary / S. U. Honcharenko. — K. : Lybid, 1997. — 376 p. (in Ukrainian)

4. Horovaya V. I., Petrova N. F. Innovational activiry of educator // Modern problems of science and education. - 2009. — № 3 - P. 149-153. (in Russian)

5. Encyclopaedia of education / Academy of pedagogical sciences of Ukraine; editor in chief V.G. Kremen. - K. : Yurinkom Inter, 2008. - 1040 p. (in Ukrainian)

6. National program «Osvita» («Ukraine XXI century») [online]. - Available from: http://zakon1.rada.gov.ua). (in Ukrainian)

7. Guk Y. O., Sokolyuk O. M. Internet oriented pedagogical sciences: problems of concept interpretation [online] // Guk. Y. O., Sokolyuk O. M. - Available from: http://lib.iitta.gov.ua) (in Ukrainian)

8. Ivanenko K. V. Educational system as factor in the formation and development of personality / Ivanenko K. V. // Theoretical and methodical problems in children and school youth education : Collection of scientific papers. - Issue 15, book 1. - Kamenetz-Podolsk : Publisher entrepreneur Zvoleyko D. H., 2011. - 528 p. (in Ukrainian)

9. Kiyashko O. O. Innovational pedagogical technologies in preparation of junior specialists in higher education institution of I-II accreditation level : ph.d in pedagogical sciences thesis : 13.00.04 / Kiyashko O. O. - Lugansk, 2001. - 262 p. (in Ukrainian)

10. Pedagogical technologies: theriy and practice : textbook / edited by prof. M. V. Hrinyova. - Polt. state. ped. University. them. V. G. Korolenka. — P. : ASMI, 2006. - 230 p. (in Ukrainian)

11. Petrova N. F. Pedagogical technologies of educator's management activity // Modern problems of science and education. - 2009. — № 2. - P. 77-78. (in Russian)

12. Pyehota O .M. Educational technologies : Textbook / [O. M. Pyehota, A. Z. Kiktenko, O. M. Lyubarska and others]. — K. : ASK, 2002. — 255 p. (in Ukrainian)

13. Regulations on distance learning [online]. - Available from: http://zakon4.rada.gov.ua). (in Ukrainian)

14. Pyatakova G. P., Zayachkivska N. M. Modern pedagogical technologies and methods of their use in higher education : Textbook for students and mastersof higher education. — Lviv : Publishing Center LNU of I.Franko, 2003. - 55 p. (in Ukrainian)

15. Selevko G. K. Modern education technologies : textbook. — M. : National education, 1998. — 589 p. (in Russian)

16. Selevko G. K. Encyclopedia of education technologies: in 2 vol., vol.1 SDI schoole technologies, 2006. 816 p. (series "Encyclopedia of education technologies").(in Russian) 